\title{
Pengembangan dan Analisis Aplikasi Penjualan Mobil dan Suku Cadang pada CV Putra Iman
}

\author{
Mei P. Kurniawan ${ }^{1}$, Barka Satya $^{2}$ \\ ${ }^{1}$ Program Studi Sistem Informasi, Fakultas Ilmu Komputer, \\ Universitas AMIKOM Yogyakarta \\ meikurniawan@amikom.ac.id \\ ${ }^{2}$ Program Studi Teknik Informatika, Fakultas Ilmu Komputer, \\ Universitas AMIKOM Yogyakarta \\ barka.satya@amikom.ac.id
}

\begin{abstract}
The needs of people that is especially mobility efficiency drive people to use personal transportation. The escalation of car sales for each year has proven that people prefer to use personal transportation than public transportation. The lack of information regarding car seller showroom causes the costumers must come to showroom to get information about car technology and facility from the salesman. Un-efficient interaction between customer and salesman is the main problem of this research. It is proposed that ecommerce approach can solve the main problem. The case study is conducted at CV. Putra Imam which is a car showroom and spare part seller. The web based application will be included transaction feature, car specification page, and prices of car and spare part page. The website is tested to 10 users, and each user is interviewed. The result is shown that 9 of 10 users stated that the website is informative and facilitates the user transaction.
\end{abstract}

Keywords: e-Commerce, Information system, Transaction feature, Showroom

\begin{abstract}
ABSTRAK
Seiring dengan kebutuhan masyarakat dengan efisiensi mobilitas, membuat kebutuhan terhadap suatu media transportasi tidak lagi menjadi kebutuhan sekunder, dibuktikan dengan penjualan kendaraan yang terus meningkat setiap tahunnya terutama dengan penjualan mobil. Terbatasnya media informasi pada suatu showroom penjualan mobil membuat calon pembeli atau calon pembeli harus datang langsung untuk mengetahui fasilitas dan teknologi mobil tersebut. Ketidak efisienan interaksi antara calon pembeli dan agen penjual menjadi masalah utama pada penelitian ini. Penerapan media e-commerce diajukan untuk menyelesaikan permasalah tersebut. Studi kasus dilakukan pada CV. Putra Iman yang merupakan showroom penjualan mobil dan suku cadang. Aplikasi yang berbasis website ini nantinya akan diisi dengan fitur transaksi penjualan mobil, suku cadang dan lainnya, informasi mengenai ketersediaan mobil dan juga suku cadang dapat langsung dilihat calon pembeli pada website e-comerce tersebut serta informasi mengenai spesifikasi barang yang di pasarkan pada showroom. Kemudian website ini diuji ke 10 pengguna dan dilakukan wawancara ke pengguna tersebut. Dari hasil pengujian diperoleh fakta bahwa 9 dari 10 pengguna menyatakan website ini informatif dan memudahkan dalam melakukan pembayaran.
\end{abstract}

Kata kunci: e-Commerce, Sistem informasi, Fitur transaksi, Showroom

\section{PENDAHULUAN}

Saat ini perkembangan pada bidang ilmu teknologi informasi (Dan \& Sistem, 2015) sangatlah terasa manfaatnya, banyaknya perusahaan yang menerapkan IT untuk usahanya menghasilkan tingkat efisiensi serta kemudahan manajemen yang lebih baik dibandingkan dengan cara manual. CV. Putra Iman merupakan showroom mobil yang bergerak dalam bidang jual beli mobil serta suku cadang, kegiatan promosi yang masih dilakukan dengan cara manual masih sering menemukan hambatan-hambatan yang membuat kurang efektifnya pemasaran produk. Banyaknya variasi produk mobil yang dijual juga membuat konsumen kesulitan untuk memilih mobil yang sesuai dengan kebutuhan. Hal tersebut tentu akan menjadi kendala jika para calon pembeli memiliki kesibukan yang padat atau tidak memiliki banyak waktu luang untuk mencari informasi 
mengenai produk yang ingin dibeli di CV. Putra Iman. Dengan melihat permasalahan yang ada maka dari itu peneliti akan mencoba untuk merancang suatu sistem informasi e-comerce berbasis website yang diharapkan dapat mempermudah kegiatan transaksi penjualan serta mengurangi pekerjaan dan meningkatkan efesiensi serta ektifitas dari perusahaan tersebut.

\section{METODE PELAKSANAAN}

Permasalahan tentang ketidak efesiennya interaksi antara calon pembeli dan penjual dari $\mathrm{CV}$. Putra Imam dapat diselesaikan dengan sistem informasi e-commerce berbasis website. Untuk mengetahui kapabilitas dari sistem informasi berbasis website tersebut diperlukan analysis SWOT. Analisis SWOT (Susanto \& Zakaria, 2017)adalah metode perencanaan strategi yang digunakan untuk mengevaluasi kebutuhan (Strength), kelemahan (Weakness), peluang (Opportunity), dan ancaman (Threats) dalam suatu proyek atau perusahaan. Alasan dipilihnya analisis SWOT adalah sebagai berikut:

a. Gambaran umum dari sistem informasi dapat diketahui dengan cepat dan tepat.

b. Kelebihan dan kekurangan Sistem Informasi yang dirancang dapat dianalisis secara sistematis.

\subsection{Analisis SWOT}

Berikut merupakan analisis SWOT pada aplikasi ini :

\section{a) Strength (Kekuatan)}

1. Website mampu menampilkan informasi yang dibutuhkan calon pembeli untuk mengetahui spesifikasi dari barang otomotif yang akan dibeli.

2. Website mampu melakukan penyimpanan data-data penting riwayat penjualan.

3. Website mampu melakukan pencetakan data transaksi.

4. Website mampu melakukan manajemen data barang yang akan ditampilkan pada website client.

5. Tampilan website yang cukup mudah dipahami sehingga pengguna dapat menjalankan website sesuai dengan kebutuhan.

Tabel 1. Analisis SWOT untuk CV. Putra Iman

\begin{tabular}{|c|c|c|}
\hline INTER & $\begin{array}{c}\text { Strength } \\
\text { (Kekuatan) }\end{array}$ & $\begin{array}{l}\text { Weakness } \\
\text { (Kelemahan) }\end{array}$ \\
\hline $\begin{array}{c}\text { Opportunity } \\
\text { (Peluang) }\end{array}$ & $\begin{array}{l}\text { Strategi SO } \\
\text { 1. Pencarian informasi secara } \\
\text { tradisional dapat digantikan } \\
\text { dengan sebuah website. } \\
\text { 2. Transaksi tradisional dapat } \\
\text { dilakukan secara online dengan } \\
\text { fitur transaksi yang disediakan } \\
\text { di website. }\end{array}$ & $\begin{array}{l}\text { Strategi WO } \\
\text { 1. } \begin{array}{l}\text { Mengembangkan website yang } \\
\text { membutuhkan koneksi yang rendah. }\end{array} \\
\text { 2. Mengembangkan website dengan } \\
\text { keamanan berlapis seperti dengan } \\
\text { memberikan fitur encripsi pada } \\
\text { pertukaran data dari server ke client. }\end{array}$ \\
\hline $\begin{array}{c}\text { Threats } \\
\text { (Ancaman) }\end{array}$ & $\begin{array}{l}\text { Strategi } \boldsymbol{S T} \\
\text { 1. Dengan banyaknya perusahaan } \\
\text { yang bergerak dibidang } \\
\text { otomotif, maka peningkatan } \\
\text { fungsionalitas dan fitur yang } \\
\text { secara berkala perlu dilakukan } \\
\text { untuk meningkatkan layanan } \\
\text { ke konsumen. }\end{array}$ & $\begin{array}{l}\text { Strategi WT } \\
\text { 1. } \quad \text { Mengembangkan website } \\
\text { berdasarkan kelebihan dan } \\
\text { kelemahan dari website pesaing. } \\
\text { Sehingga website CV. Putra Imam } \\
\text { dapat terus mengungguli dengan } \\
\text { website pesaing. }\end{array}$ \\
\hline
\end{tabular}




\section{b) Weakness (Kelemahan)}

1. Harus menggunakan koneksi Internet untuk mengakses dari jarak jauh.

2. Rentan diretas oleh pihak - pihak yang tidak bertanggung jawab.

\section{c) Oppotunities (Peluang)}

1. Mampu meningkatkan penjualan barang otomotif pada perusahaan.

2. Mampu meningkatkan promosi perusahaan.

3. Manajemen data transaksi yang lebih akurat dengan teknik terkomputerisasi.

\section{d) Threats (Ancaman)}

1. Ancaman untuk website e-comerce ini adalah persaingan antar perusahaan yang mampu membuat website dengan fitur yang lebih modern sehingga calon pembeli lebih menyukai website pesaing tersebut.

\section{HASIL DAN PEMBAHASAN}

Keluaran dari penelitian ini adalah sebuah website yang memiliki fitur transaksi dan memiliki informasi yang lengkap tentang showroom CV. Putra Iman.

\subsection{Hasil Perancangan Website}

Halaman utama merupakan tampilan dimana calon pembeli akan melihat tampilan awal saat website dikases, pada halaman ini akan tampil beberapa menu yang dapat dipilih calon pembeli sesuai dengan kebutuhan, tampilan halaman utama yang dirancang pada website ditunjukan pada Gambar 1.
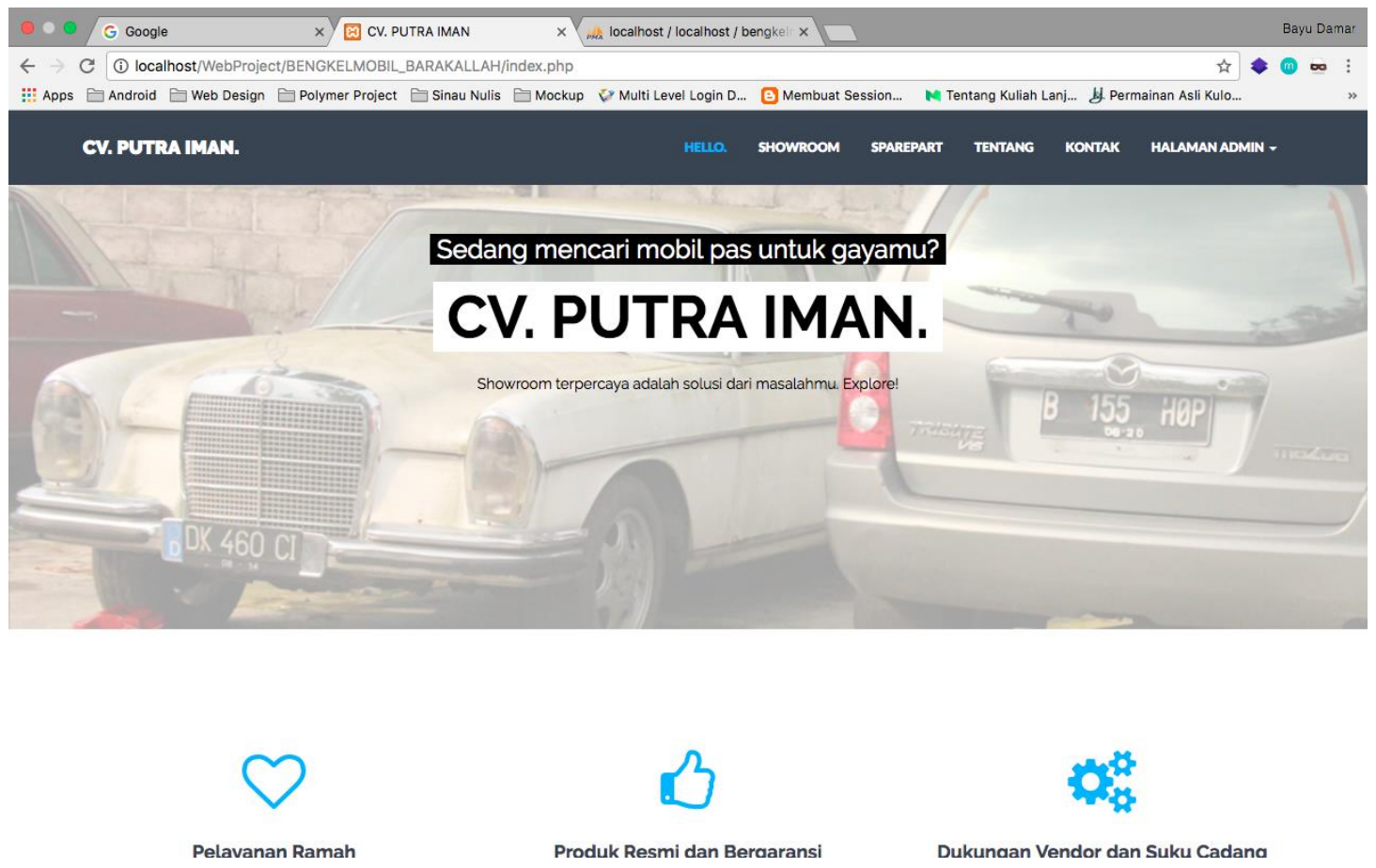

Gambar 1. Tampilan Halaman Utama

Halaman selanjutnya merupakan halaman dari menu showroom dimana pada menu ini akan ditampilkan pruduk-produk mobil yang dijual pada CV. Putra Iman, tampilan dari halaman showroom pada website ditunjukan pada Gambar 2. 


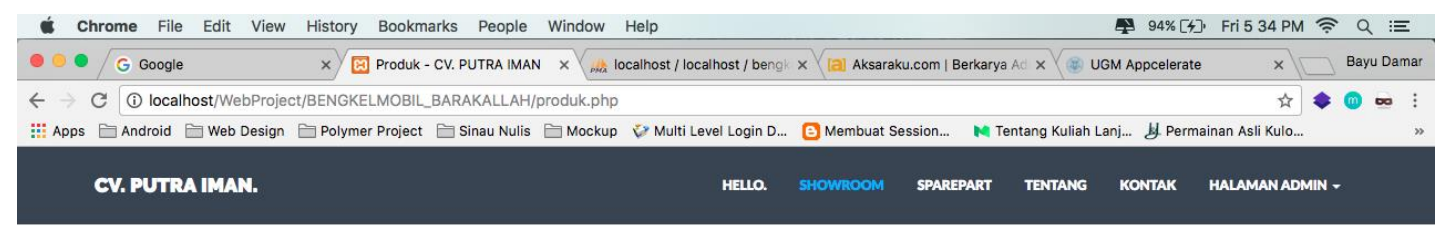

Kami menyediakan berbagai pilihan untuk anda. Pilih sesuai keinginanmu.
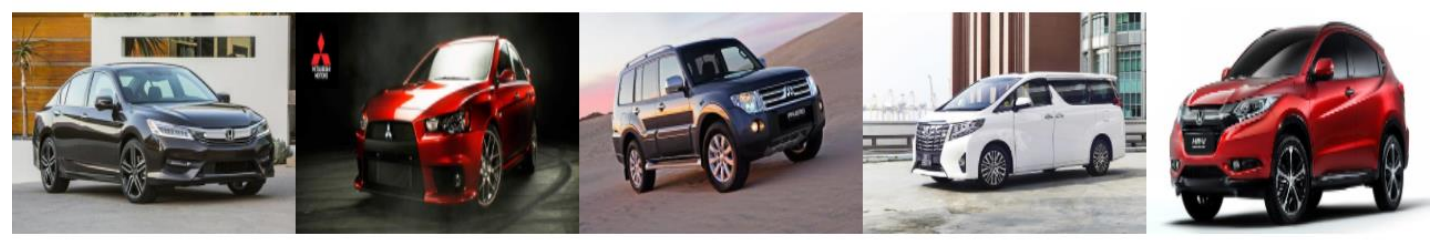

\section{9.}

Gambar 2. Tampilan Halaman Menu Showroom

Dan ketika calon pembeli ingin melihat detail dari produk yang dipasarkan maka calon pembeli cukup melakukan klik pada gambar produk yang dipilih, setelah calon pembeli memilih produk maka akan tampil detail dari produk yang dipilih, dan pada Gambar 3 ditunjukan tampilan dari website ini.

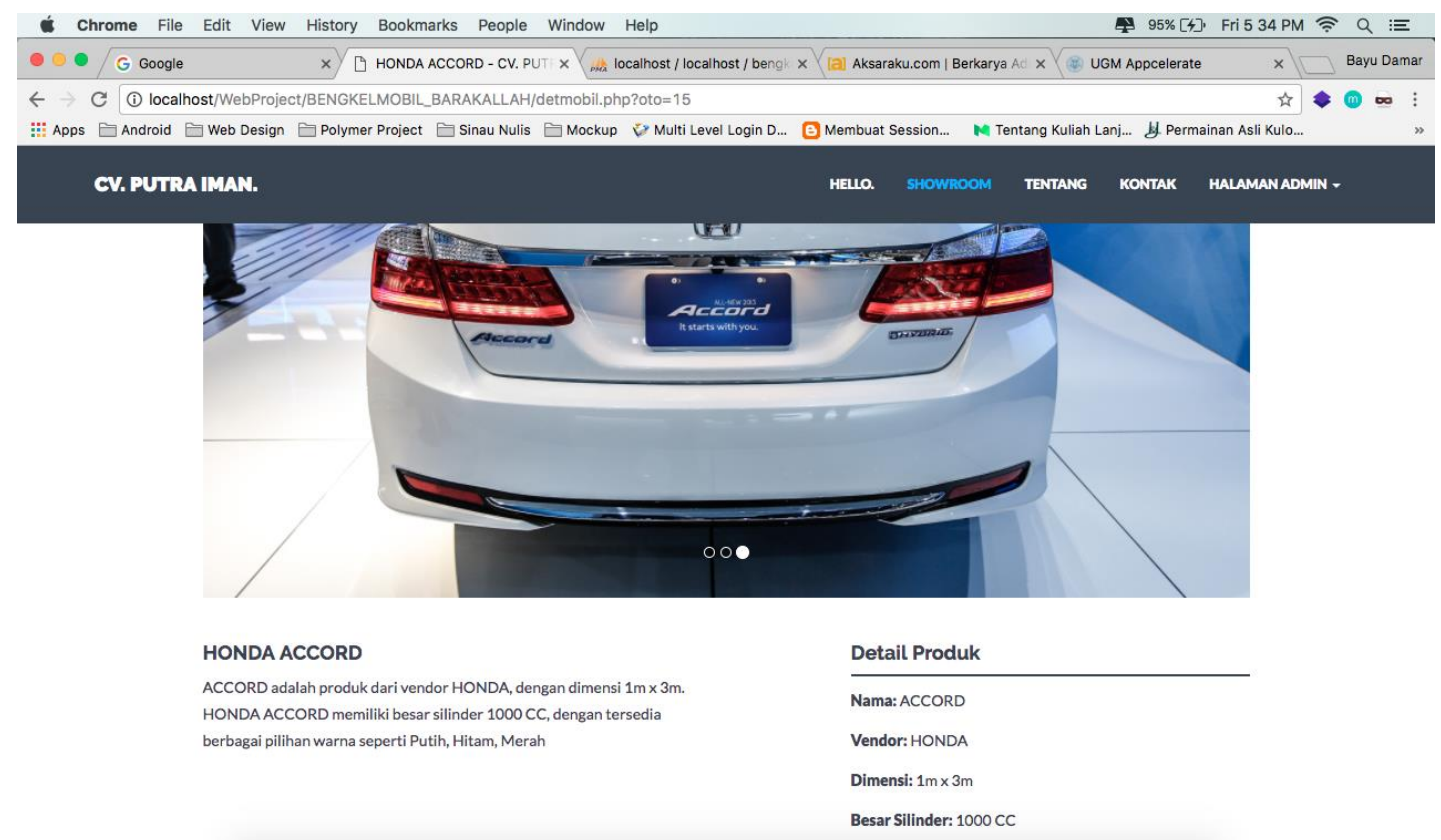

\section{4.}

Gambar 3. Tampilan Halaman Detail Produk Mobil

Menu selanjutnya merupakan menu sparepart, menu sparepart sendiri berisi produkproduk sparepart yang dijual pada CV. Putra Iman, dan berikut merupakan tampilan dari menu sparepart pada website seperti ditunjukan pada Gambar 4. 


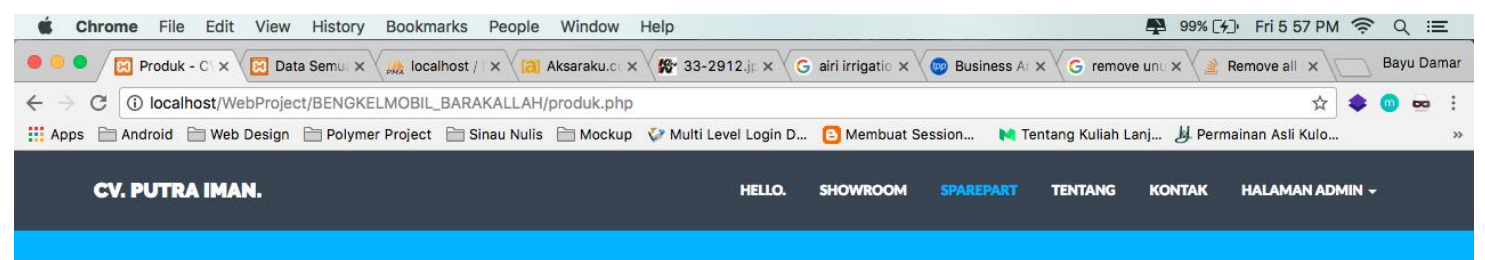

\section{Kami juga menyediakan berbagai sparepart untuk mobil kesayangan anda.}

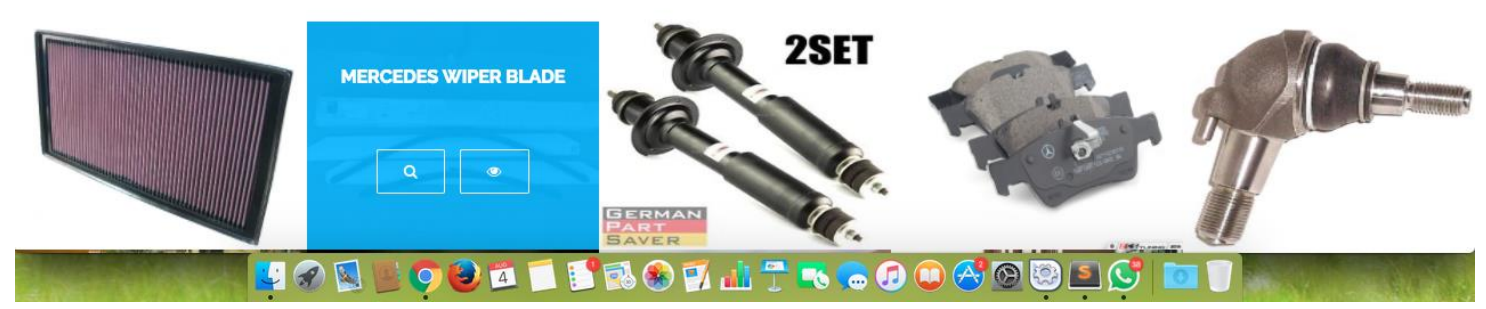

Gambar 4. Tampilan Halaman Menu Spareparts

Suatu website client/server membutuhkan suatu halaman tersendiri yang akan dikelola oleh admin atau pihak yang bertanggung jawab terhadap konten yang tersedia dari website yang ditujukan untuk calon pembeli, maka dari itu peneliti juga menyediakan halaman portal admin yang di rancang untuk kegiatan manajemen tampilan website dan lainnya. Untuk memasuki halaman admin terlebih dahulu admin harus melakukan login dengan akun yang telah dibuat, berikut merupakan tampilan menu login pada portal admin sesuai dengan Gambar 5 .
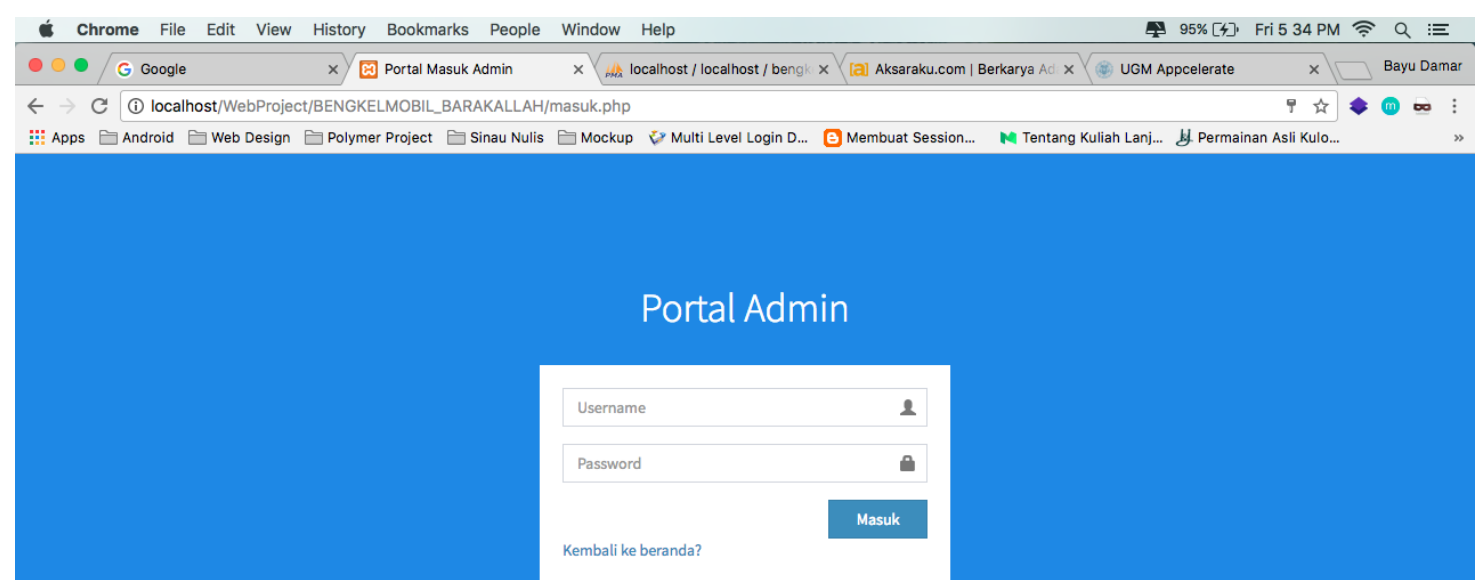

Brand Bengkel

\section{4.}

Gambar 5. Tampilan Login Portal Admin 
Setelah admin berhasil login, maka admin akan melihat halaman beranda dari portal admin berserta seluruh fitur yang dirancang untuk website, berikut merupakan halaman beranda portal admin pada website yang diilustrasikan pada Gambar 6.

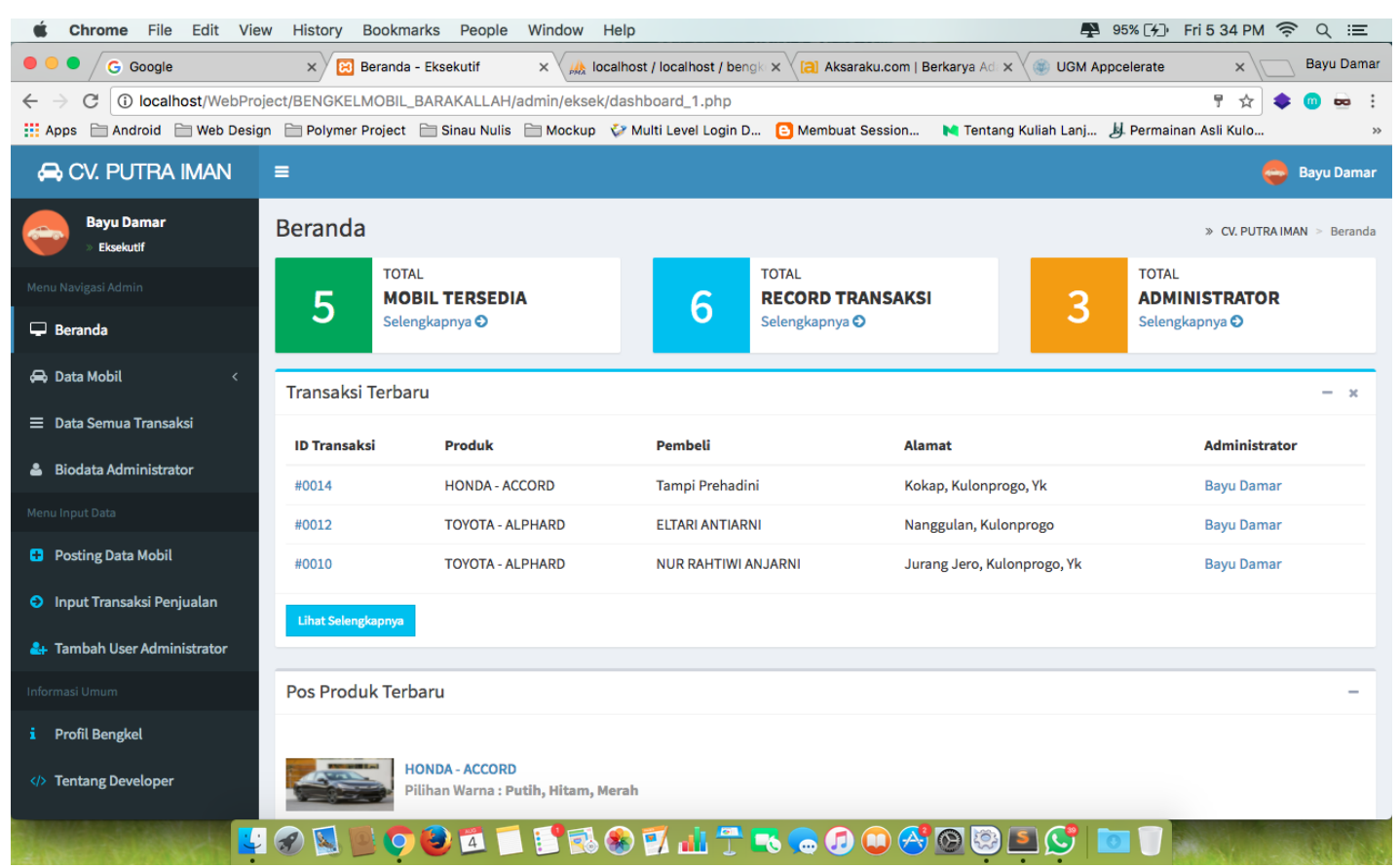

Gambar 6. Tampilan Beranda Portal Admin

Dari gambar diatas kita dapat melihat bahwa terdapat beberapa menu untuk melakukan pengaturan terhadap website calon pembeli, dan salah satunya adalah pengaturan untuk perekaman setiap transaksi penjualan yang tersimpan.

Selain data transaksi menu yang lainnya adalah menu untuk posting data mobil yang akan ditampilkan pada website cutomer, dan berikut merupakan tampilan untuk posting data mobil pada website yang ditunjukan pada Gambar 7.

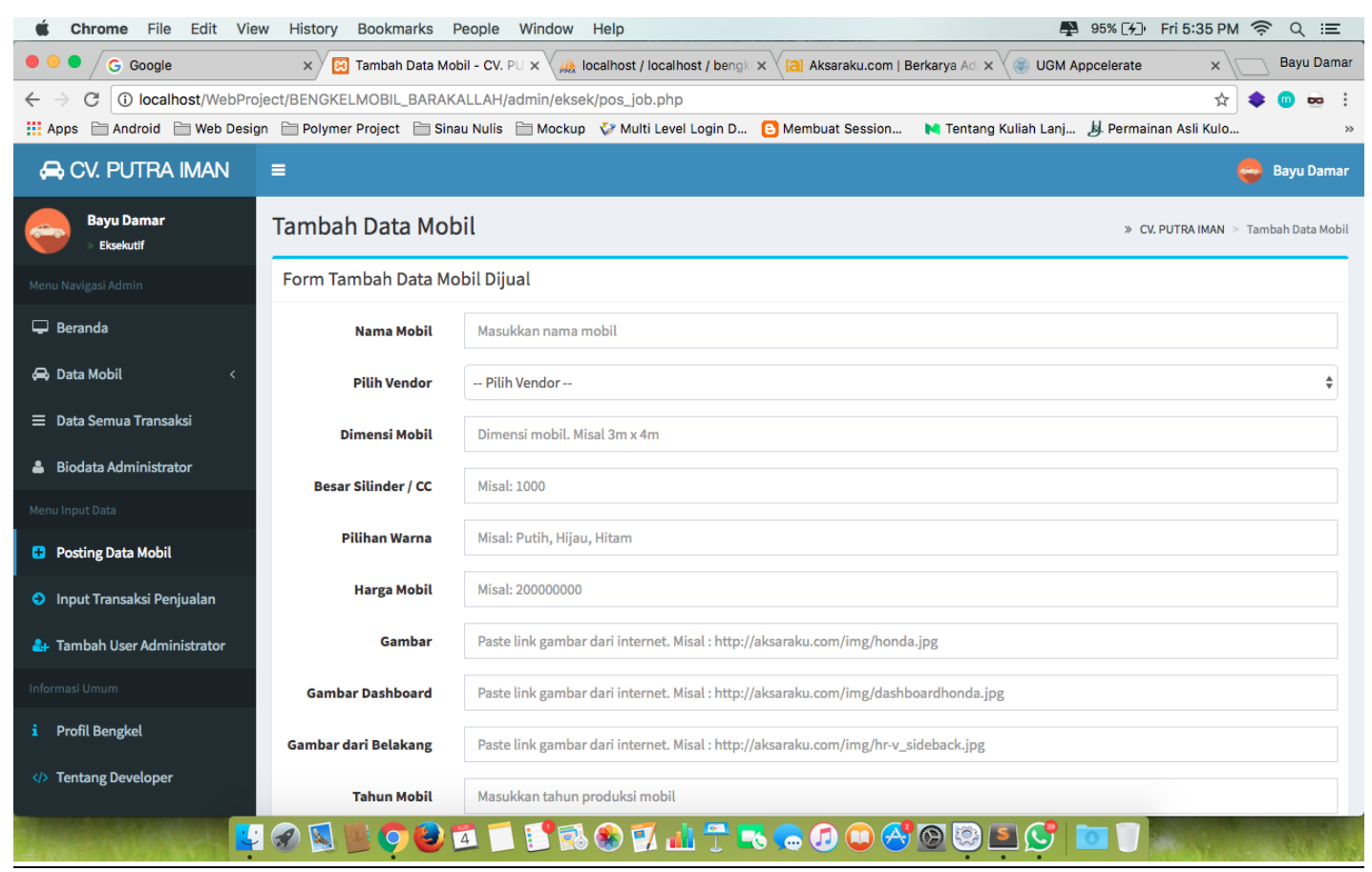

Gambar 7. Tampilan Input Data Mobil Portal Admin 


\subsection{Pembahasan}

Setelah website siap untuk dilakukan pengujian maka database dan website diunggah di server hosting. Kemudian dipilih 10 pengguna secara acak dan dilakukan pengujian dengan cara memberikan pengguna akses ke website dan dilakukan wawancara untuk mengetahui kesan pengguna terhadap website yang diuji. Dari pengujian diperoleh bahwa 9 dari 10 pengguna menyatakan bahwa website ini memberikan informasi yang lengkap dan juga memudahkan pengguna untuk melakukan transaksi. Karena dapat dilakukan secara elektronis.

\section{KESIMPULAN}

Website merupakan sarana yang efektif dan efisien untuk menyediakan informasi dan transaksi elektronik untuk perusahaan yang bergerak di bindang otomotif. Oleh karena itu, pendekatan e-commerce berbasis website terbukti mampu memberikan kepuasan kepada pengguna. Harapannya interaksi yang efisien ini dapat meningkatkan penjualan dari showroom CV. Putra Imam.

\section{DAFTAR PUSTAKA}

Dan, A., \& Sistem, P. (2015). Informasi Penjualan Piranti Multimedia Berbasis Web ( Studi Kasus: PT Sistem Kreasi Inovasi Indonesia). In Seminar Nasiona Sains dan Teknologi Terapan.

Susanto, \& Zakaria. (2017). Analisis Swot Sebagai Dasar Perumusan Strategi Pemasaran di Klinik Pratama PKU Muhammadiyah Cangkringan. Proceeding Healt Architecture, 1(1). 
JPP IPTEK, Mei 2018, Vol. 2, No. 1

Halaman ini sengaja dikosongkan 